\title{
PENERAPAN STUDENT TEAMS ACHIEVEMENT DIVISION (STAD) UNTUK MENINGKATKAN AKTIVITAS DAN HASIL BELAJAR IPA SISWA KELAS IXC SMP NEGERI 1 GEMOLONG SRAGEN
}

\author{
Tukiman \\ Guru SMP Negeri 1 Gemolong, Kabupaten Sragen \\ ipa_tukiman@yahoo.co.id
}

\begin{abstract}
This research is aimed at improving science learning result and activities on electricity topic for the ninth grade students of class IXC SMP N 1 Gemolong through teaching and learning process which implemented STAD. The research subject consists of 32 students, 16 male and 16 female. The research duration is 5 months, since July 2016 until November 2016. This research consists of two cycles in one Competence Standard. The first cycle is "Dynamic Electricity" The second cycle is "The Source of Electricity Current" Each cycle consists of four steps : planing, action, observation, and reflection. The data of science learning activity since the begining until the end are as follows: the early condition of learning activity is 53\%, in first cycle the average of learning activity is $84,4 \%$, the average of the end condition (the second cycle) is $88,1 \%$. Whereas the average of the early data of learning result is 73, the average of first cycle is 76, and the average of second cycle is 84 . Based on the theory and action result, it can be concluded that STAD can improve science activity and learning result on electricity topic for the students of class IXC SMP N 1 Gemolong in the first semester of 2016/2017 academic year.
\end{abstract}

Keywords: STAD, learning activity, learning result

\begin{abstract}
Abstrak. Penelitian ini bertujuan untuk meningkatkan aktivitas dan hasil belajar IPA materi kelistrikan siswa kelas IXC SMP Negeri 1 Gemolong pada semester I tahun pelajaran 2016/2017 melalui pembelajaran yang menerapkan STAD. Subjek penelitian adalah siswa yang berjumlah 32 anak, 16 laki-laki dan 16 perempuan. Waktu penelitian selama 5 bulan yaitu bulan Juli 2016 sampai dengan bulan November 2016. Penelitian terdiri dari dua siklus dalam satu standar kompetensi. Siklus I untuk materi "Listrik Dinamis" dan siklus II untuk materi "Sumber Arus Listrik" pada tiaptiap siklus terdiri dari 4 tahap yaitu perencanaan, pelaksanaan tindakan, pengamatan dan refleksi. Data aktivitas belajar IPA dari awal sampai dengan kondisi akhir adalah sebagai berikut, kondisi awal aktifitas belajar 53\%, pada siklus I aktivitas belajar rerata $84,4 \%$ kondisi akhir (siklus II) rerata $88,1 \%$. Data hasil belajar pada kondisi awal rerata 73, pada siklus I rerata 76 dan pada kondisi akhir (siklus II) rerata 84 . Berdasarkan kajian teori dan hasil tindakan, simpulan hasil penelitian bahwa secara teoritik maupun empirik "Penerapan Student Teams Achievement Division (STAD) dapat meningkatkan aktivitas dan hasil belajar IPA materi kelistrikan bagi peserta didik kelas IXC SMP Negeri 1 Gemolong Semester I Tahun Pelajaran 2016/2017.
\end{abstract}

Kata kunci: STAD, aktivitas belajar, hasil belajar. 


\section{Pendahuluan}

\section{A. Latar Belakang Masalah}

Berdasarkan pengalaman peneliti selaku guru IPA SMP Negeri 1 Gemolong yang mengajar di kelas IXC diketemukan bahwa kendala pembelajaran di kelas IXC adalah kurangnya aktivitas peserta didik dalam pembelajaran. Aktivitas yang dimaksud adalah aktivitas yang mendukung proses pembelajaran, seperti mendengarkan, membaca buku, mencatat, bertanya dan sebagainya.

Aktivitas peserta didik dalam proses pembelajaran masih kurang, kecuali aktivitas mendengar dan membaca, meskipun tidak terus menerus selama proses pembelajaran. Dari 32 peserta didik kelas IXC yang aktif mendengarkan selama proses pembelajaran ada 28 anak, membaca buku pelajaran atau referensi ada 25 anak, bertanya kepada guru ada 3 anak dan menjawab pertanyaan guru ada 2 anak, membuat catatan tentang materi pelajaran ada 24 anak.

Hasil belajar yang diperoleh peserta didik juga belum mencapai harapan yang diinginkan, bahkan secara umum di kelas tersebut masih banyak peserta didik yang belajarnyabelummencapai kriteria ketuntasan minimal. Untuk materi Listrik Statis, dari 32 peserta didik kelas IXC semester I tahun pelajaran 2016/2017 dengan KKM 75, data rerata hasil belajar 73 dengan rincian : 18 peserta didik atau (56\%) memperoleh nilai di atas KKM dan 14 peserta didik (44\%) memperoleh nilai di bawah KKM.

Guru IPA di SMP Negeri 1 Gemolong telah melakukan berbagai cara agar proses pembelajaran berhasil memuaskan, dengan menerapkan berbagai metode dan menggunakan berbagai media sebagai alat bantu seperti LCD proyektor, charta, dan lain-lain. Namun demikian hasil yang dicapai masih belum memuaskan.

Keterlibatan peserta didik dalam proses pembelajaran masih rendah, misalnya sebagian besar peserta didik cenderung pasif, enggan bertanya dan berpendapat, hanya peserta didik tertentu yang mau bertanya dan menjawab pertanyaan dari guru, interaksi antar peserta didik juga masih kurang.

Untuk mengatasi permasalahan di atas, maka perlu dilakukan penelitian tindakan kelas, dalam hal ini yang dipilih yaitu pembelajaran yang menerapkan STAD (Student Teams Achievement Divisions). Melalui pembelajaran model STAD diharapkan dapat meningkatkan aktivitas dan hasil belajar peserta didik kelas IXC di SMP Negeri 1 Gemolong.

Metode pembelajaran Student Teams AchievementDivision(STAD) dikembangkan oleh Robert Slavin dan kawan-kawannya dari Universitas John Hopkin (Hamdayama, 2014:115).

Hamdayama (2014:117) menjelaskan langkah-langkah penerapan pembelajaran tipe STAD adalah sebagai berikut: (1) Guru menyampaikan materi pembelajaran kepada peserta didik sesuai kompetensi dasar yang akan dicapai; (2) Guru membentuk kelompok yang terdiri dari 4-5 orang dengan kemampuan yang berbeda-beda (tinggi, sedang, rendah), jika mungkin anggota kelompok berasal dari suku, ras budaya dan jenis kelamin yang berbeda-beda; (3) Bahan yang telah dipersiapkan, didiskusikan dalam kelompok untuk mencapai kompetensi dasar; (4) Guru memfasilitasi peserta didik untuk membuat rangkuman, mengarahkan dan memberikan penegasan pada materi pelajaran yang telah dipelajari; (5) Guru memberikan kuis/tes kepada setiap peserta didik secara indiviual; (6) Guru memberikan penghargaan pada kelompok berdasarkan nilai peningkatan hasil belajar individual dari skor awal ke skor kuis tersebut.

Hamdayama (2014:117) menjelaskan gagasan utama dibalik model STAD adalah untuk memotivasi para peserta didik untuk mendorong dan membantu satu sama lain dalam menguasai materi pelajaran. Jika peserta didik ingin mendapatkan penghargaan kelompok, mereka harus membantu teman sekelompok dalam memahami materi yang 
dipelajari, karena setiap anggota akan menyumbangkan nilai atau skor kepada kelompoknya.

Pepatah Cina mengatakan: Jika saya mendengar, saya lupa; jika saya melihat, saya ingat; jika saya melakukan, saya paham; Edgar Dale dalam Sani (2015:60-61) menyatakan bahwa daya ingat peserta didik terkait proses pembelajaran yang dilakukan, adalah sebagai berikut: (a) Peserta didik mungkin mengingat $20 \%$ dari apa yang dibaca atau didengar, (b) Peserta didik mungkin mengingat 30\% dari apa yang dilihat, (c) Peserta didik mungkin mengingat $50 \%$ dari apa yang didengar dan dilihat, (d) Peserta didik mungkin mengingat $75 \%$ dari apa yang dikatakan, dan (e) Peserta didik mungkin mengingat $90 \%$ dari apa yang dilakukan.

Paul D. Dierich dalam Sardiman ( 2016:101) membagi aktivitas belajar ke dalam 8 kelompok, yaitu: (1) Kegiatan visual (visual activities), diantaranya membaca, melihat, mengamati; (2) Kegiatan lisan (oral activities) diantaranya mengemukakan fakta, mengajukan pertanyaan, memberi saran, mengemukakan pendapat, wawancara, dan diskusi; (3) Kegiatan mendengarkan (listening activities); (4) Kegiatan menulis (writing activities), menulis cerita, menulis laporan, menulis karangan, membuat rangkuman, mengerjakan tes, menyalin, mencatat; (5) Kegiatan menggambar (drawing activities), diantaranya menggambar, membuat grafik, membuat chart, membuat diagram, membuat peta, membuat sketsa; (6) Kegiatan metrik (motor activities), antara lain melakukan percobaan, melaksanakan pameran, mereparasi, beternak, menari, berkebun; (7) Kegiatan mental (mental activities), misalnya merenungkan, mengingat, memecahkan masalah, menganalisis, dan membuat keputusan; (8) Kegiatan emosinal (emotional activities), seperti minat, merasa bosan, gembira, semangat, bergairah, berani, tenang, dan lain-lain.

Slameto dalam Jihad (2013:2) merumuskan belajar sebagai suatu proses usaha yang dilakukan seseorang untuk memperoleh suatu perubahan tingkah laku yang baru secara keseluruhan, sebagai hasil pengalamannya sendiri dalam interaksi dengan lingkungannya. Lebih jauh Slameto memberikan ciri tentang perubahan tingkah laku yang terjadi dalam belajar sebagai berikut: (1) Terjadi secara sadar; (2) Bersifat kontinu dan fungsional; (3) Bersifat positif dan aktif; (4) bukan bersifat sementara; (5) Bertujuan dan terarah; dan (6) Mencakup seluruh aspek tingkah laku.

Kategori belajar mutahir yang dibuat oleh komisi Delor dari Unesco dalam Jihad (2013:3) terbagi menjadi empat pilar yaitu: (1) belajar bagaimana belajar (learning to know); (2) belajar berbuat (learning to do); (3) belajar hidup bersama (learning to live together); dan belajar mengaktualisasikan diri (learning to be).

Dari uraian di atas perlu ditegaskan bahwa belajar merupakan suatu proses yang harus dijalani oleh yang belajar, yang melibatkan aktivitas fisik maupun psikis sehingga ia memperoleh pengalaman belajar tertentu dan hasil belajar yang berupa pengetahuan, sikap atau keterampilan.

Hasil belajar adalah kemampuan yang diperoleh anak setelah melalui proses kegiatan belajar. Menurut Benjamin S Bloom ada tiga ranah (domain) hasil belajar, yaitu kognitif, afektif dan psikomotorik. Menurut A.J. Romizowski dalam Jihad (2013:14) hasil belajar merupakan keluaran (output) dari suatu sistem pemrosesan masukan (input). Masukan dari sistem tersebut berupa bermacammacam informasi sedangkan keluarannya adalah perbuatan atau kinerja (performance), demikian menurut Abdurrahman dalam Jihad (2013:14).

Dapat disimpulkan bahwa hasil belajar adalah pencapaian bentuk perubahan perilaku yang cenderung menetap dari ranah kognitif, afektif, dan psikomotorik dari proses belajar yang dilakukan dalam waktu tertentu.

\section{B. Metode}

Penelitian dilaksanakan di kelas IXC SMP Negeri 1 Gemolong Semester 1 Tahun 
Pelajaran 2016/2017, dengan alamat jalan Diponegoro No 60 Gemolong, kabupaten Sragen, yang berjumlah 32 anak terdiri dari 16 anak laki-laki dan 16 anak perempuan. Penelitian dilakukan selama 5 bulan mulai bulan Juli 2016 sampai dengan bulan November 2016.

Data yang diambil dalam penelitian tindakan kelas ini meliputi: 1) data aktivitas belajar IPA kondisi awal, 2) data hasil belajar IPA kondisi awal, 3) data pelaksanaan tindakan siklus I, 4) Data aktivitas belajar IPA siklus I, 5) Data hasil belajar IPA siklus I, 6) data pelaksanaan siklus II, 7) data aktivitas belajar IPA siklus II, dan 8) data hasil belajar IPA siklus II.

Teknik pengumpulan data dengan 1) dokumentasi aktivitas dan hasil belajar IPA kondisi awal; 2) pengumpulan data aktivitas belajar IPA pada siklus I dan II menggunakan lembar pengamatan aktivitas belajar IPA; 3) pengumpulan data hasil belajar IPA silus I dan II menggunakan teknik tes tertulis.

Validasi data aktivitas belajar dilakukan dengan cara melibatkan pengamat teman sejawat, disamping peneliti melakukan pengambilan data sendiri, sehingga data dari peneliti dan pengamat saling melengkapi. Data hasil belajar IPA siklus I dan II yang diperoleh dengan teknik tes tertulis, divalidasi dengan cara membuat kisi-kisi soal.

Data aktivitas belajar selama dilakukan tindakan dan data hasil belajar IPA kondisi awal, hasil belajar IPA siklus I, dan hasil belajar IPA siklus II, dianalisis menggunakan teknik deskriptif komparatif yang membandingkan antara data kondisi awal, data pada tindakan siklus I dan data tindakan siklus II.

Metode yang digunakan dalam penelitian ini adalah Penelitian Tindakan Kelas (PTK), dengan tindakan yang terdiri dari dua siklus. Setiap siklus meliputi perencanaan, tindakan, pengamatan dan refleksi. Perencanaan tindakan meliputi penyusunan RPP, lembar pengamatan, kisi-kisi dan soal tes, menyediakan media/sumber belajar, dan menyiapkan alat dokumentasi. Pelaksanan tindakan, meliputi kegiatan pembelajaran yang merupakan pelaksanaan RPP yang telah disusun. Pengamatan merupakan kegiatan yang dilakukan untuk pengambilan data selama pelaksanaan tindakan. Refleksi yaitu kegiatan yang dilakukan oleh peneliti bersama pengamat membahas secara kritis tentang perubahan yang terjadi pada peserta didik, guru dan suasana kelas untuk mengambil keputusan.

\section{Hasil Penelitian Dan Pembahasan \\ A. Deskripsi Data Kondisi Awal}

Data aktivitas peserta didik pada kondisi awal menunjukkan kriteria kurang, dari 32 peserta didik kelas IXC rerata aktivitas yaitu sebesar 53\%. Deskripsi data hasil belajar IPA awal. Data hasil belajar pada kondisi awal yaitu : rerata nilai 73 , nilai tertinggi 100 , nilai terendah 45 , jumlah peserta didik yang mencapai tuntas belajar 18 anak.

\section{Deskripsi Data Siklus I}

Hasil pengamatan terhadap aktivitas belajar peserta didik selama mengikuti pembelajaran yang meliputi aktivitas : 1) mendengar; 2). bertanya; 3) menjawab; 4) membaca, 5) menulis. Dari lima indikasi tersebut menghasilkan rerata prosentase aktivitas belajar sebesar 84,4\%. Data hasil belajar peserta didik kelas IXC yang terdiri dari 32 anak, materi Listrik Dinamis setelah pelaksanaan siklus I selesai, nilai rerata 76 , nilai tertinggi 100 , nilai terendah 45 , jumlah tuntas belajar 21 anak, jumlah tidak tuntas belajar 11 anak.

\section{Deskripsi Data Siklus II}

Hasil pengamatan terhadap aktivitas belajar peserta selama mengikuti pembelajaran yang meliputi aktivitas : 1) mendengar; 2). bertanya; 3) menjawab; 4) membaca, 5) menulis. Dari lima indikasi tersebut menghasilkan rerata prosentase aktivitas belajar sebesar $88,1 \%$. Data hasil belajar peserta didik kelas IXC materi Sumber Arus Listrik yang diperoleh dari Ulangan Harian setelah pelaksanaan siklus II selesai, dengan nilai rerata 84 , niai tertinggi 95 , nilai 
terendah 60, jumlah tuntas belajar 27 anak, jumlah tidak tuntas 5 anak.

\section{B. Hasil Tindakan}

Setelah diadakan tindakan pada siklus I dan siklus II, aktivitas belajar peserta didik yang meliputi : 1) mendengar; 2). bertanya; 3) menjawab; 4) membaca, dan 5) menulis mengalami peningkatan. Pada kondisi awal aktivitas belajar rerata $53 \%$, pada siklus I rerata $84,4 \%$ dan pada siklus II rerata $88,1 \%$. Hasil belajar setelah tindakan juga mengalami peningkatan. Hasil belajar pada kondisi awal, setelah siklus I dan setelah siklus II adalah sebagai berikut:

\begin{tabular}{llccc}
\hline \multirow{2}{*}{ No } & \multicolumn{1}{c}{ Uraian } & $\begin{array}{c}\text { Hasil Kondisi } \\
\text { awal }\end{array}$ & $\begin{array}{c}\text { Hasil Siklus } \\
\text { I }\end{array}$ & $\begin{array}{c}\text { Hasil } \\
\text { siklus II }\end{array}$ \\
\hline 1 & Nilai rerata & 73 & 76 & 84 \\
2 & Nilai tertinggi & 100 & 100 & 95 \\
3 & Nilai terendah & 45 & 45 & 60 \\
4 & Jumlah tuntas belajar & 18 anak & 21 anak & 27 anak \\
\hline
\end{tabular}

\section{Pembahasan}

Pada kondisi awal, bahwa dalam pembelajaran aktivitas peserta didik kurang, guru melaksankan pembelajaran sesuai prosedur, dan suasana kelas sebenarnya tenang tapi kurang bergairah untuk pembelajaran. Setelah dilaksanakan pembelajaran yang menerapkan STAD pada siklus I, peserta didik secara umum tampak antusias dalam belajar dengan aktivitas belajar yang lebih tinggi, guru melaksanakan pembelajaran sesuai prosedur yang disusun dan suasana kelas menjadi lebih hidup dan bergairah. Hasil refleksi merekomendasikan agar perencanaan siklusII diperbaiki dan pelaksanaannya semakin baik lagi. Pada siklus II yang perencanaanya telah diperbaiki, guru dapat melaksanakan pembelajaran sesuai rencana, peserta didik dapat melaksakan setiap tahap dengan baik, suasana pembelajaran di kelas tampak hidup dan menyenangkan, interaksi terjadi antar sesama peserta didik, antara guru dengan peserta didik dan antara peserta didik dengan sumber belajar.

Fakta menunjukkan bahwa telah terjadi peningkatan aktivitas belajar dan hasil belajar IPA materi kelistrikan melalui kegiatan belajar mengajar yang menerapkan model STAD, sehingga tujuan penelitian telah tercapai. Peneliti dan pengamat memutuskan untuk menghentikan penelitian pada siklus II.

\section{Simpulan}

Berdasarkan kajian teori dan hasil penelitian dapat diambil kesimpulan bahwa Kegiatan pembelajaran yang menerapkan STAD dapat meningkatkan aktivitas dan hasil belajar IPA materi kelistrikan bagi peserta didik kelas IXC SMP Negeri 1 Gemolong pada semester I tahun 2016/2017 dari kondisi awal aktivitas belajarnya 53\% ke kondisi akhir aktivitas belajarnya 88,1\% dan dari kondisi awal rerata hasil belajarnya 73 ke kondisi akhir rerata hasil belajarnya menjadi 84.

\section{Saran}

Peserta didik diharapkan dapat melaksanakan tahapan-tahapan kegiatan pembelajaran yang menerapkan STAD untuk meningkatkan aktivitas dan hasil belajar. Guru agar menerapkan pembelajaran STAD untuk meningkatkan aktivitas dan hasil belajar. Kepala sekolah diharapkan dapat mendorong guru menerapkan STAD dalam pembelajaran IPA untuk meningkatkan aktivitas dan hasil belajar. 


\section{Daftar Pustaka}

Daryanto. 2013. Media Kegiatan Belajar Mengajar. Yogyakarta: Gava Media.

Hamdayama, Jumanta. 2014. Model dan Metode Kegiatan belajar mengajar Kreatif dan Berkarakter. Bogor: Ghalia Indonesia.

Jihad, Asep. 2013. Evaluasi Kegiatan belajar mengajar. Yogyakarta: Multi Pressindo.

Kurniasih, Imas. 2016. Ragam Pengembangan Model Kegiatan Belajar Mengajar: Katapena.

Mudlofir, Ali. 2016. Desain Kegiatan Belajar Mengajar Inovatif. Jakarta: Raja Riyanto, Yatim. 2014. Paradigma Baru Kegiatan Belajar Mengajar. Jakarta:

Kencana Prenada media Group.

Sani, Abdullah. 2015. Inovasi Kegiatan Belajar Mengajar. Jakarta: Bumi Aksara.

Sardiman. 2016. Interaksi \& Motivasi Belajar Mengajar. Jakarta: Raja Grafindo Persada. 